UDC 773.1

\title{
NEW AND RARE SPECIES OF ORTHOCLADIINAE (DIPTERA, CHIRONOMIDAE) FROM THE CRIMEA, UKRAINE
}

\author{
V. A. Baranov \\ Department of Zoology and Animal Ecology \\ V. N. Karazin Kharkiv National University, \\ Svoboda Sq., 4, Kharkiv, Ukraine \\ E-mail: baranowiktor@gmail.com
}

Received 27 August 2011

Accepted 20 September 2011

\begin{abstract}
New and Rare Species of Orthocladiinae (Diptera, Chironomidae) from the Crimea, Ukraine. Baranov V. A. Parorthocladius korneyevi Baranov, sp. n. and Prosmittia valentinae Baranov, sp. n. from the Crimean Peninsula are described and illustrated. Three species of Orthocladiinae: Bryophaenocladius akiensis (Sasa, Shimomura et Matsuo, 1991), Corynoneura lacustris Edwards, 1924 and Metriocnemus eurynotus (Holmgren, 1883) are recorded for the first time from the Ukraine.
\end{abstract}

Key words: Chironomidae, Orthocladiinae, Parorthocladius, Prosmittia, new species, Crimean Peninsula.

Новые и редкие виды Orthocladiinae (Diptera, Chironomidae) из Крыма, Украина. Баранов В. А. Даны иллюстрированные описания Parorthocladius korneyevi Baranov, sp. n. и Prosmittia valentinae Baranov, sp. n. с Крымского полуострова. Три вида Orthocladiinae: Bryophaenocladius akiensis (Sasa, Shimomura et Matsuo, 1991), Corynoneura lacustris Edwards, 1924 и Metriocnemus eurynotus (Holmgren, 1883), - указаны впервые для фауны Украины.

Ключевые слова: Chironomidae, Orthocladiinae, Parorthocladius, Prosmittia, новые виды, Крымский полуостров.

\section{Introduction}

The subfamily Orthocladiinae is one of the largest subfamilies of non-biting midges (Chironomidae) (Ashe, Cranston, 1990). Up to now only 91 species of Orthocladiinae were recorded from Ukraine (Baranov, 2011). Orthocladiinae play a major role in epi- and metharithral communities of mountain rivers in the Crimea (Prokopov, pers. comm.). However, no comprehensive overview of the taxonomic composition of the Crimean Orthocladiinae exists (Baranov, 2011).

Studies on the chironomids in Ukraine, and particularly on the Crimean Peninsula, revealed six species previously not known from the Ukraine, of which two species are new to science and are described below.

The new species were collected on the south shore of the Crimea (where a Mediterranean climate exists), in the Crimean Mountains, and in the city of Simferopol.

\section{Material and methods}

Adults were collected mainly by using sweep nets. The material was preserved in $70 \%$ ethanol and then mounted on slides in Berlese fluid and glycerol-gelatin. Morphological terminology follows Sæther (1980). The measurements are given as ranges. Holotypes of the new species are deposited in the collection of I. I. Schmalhausen Institute of Zoology, National Academy of Sciences of Ukraine, Kyiv (SIZK); some paratypes and all other examined material are deposited in the private collection of the author (VAB).

\section{Genus Parorthocladius Thienemann, 1935}

Type species: Dactylocladius nudipennis Kieffer, 1908.

The genus includes six described species and occurs in the Holarctic, Oriental and Afrotropical Regions (Ashe, Cranston, 1990; Lui, Wang, 2005, Yamamoto, 2004, 2011).

Based on the material from China, Lui, Wang (2005) reviewed and keyed all known species of Parorthocladius. An additional species, Parorthocladius negoroi Yamamoto, 2011 was described recently (Yamamoto, 2011). There are also several undescribed species. 
Parorthocladius korneyevi Baranov, sp. n. (fig. 1, $A-C$ )

Type material. Holotype male (slide-mounted in Berlese fluid), Ukraine: Crimean Peninsula,

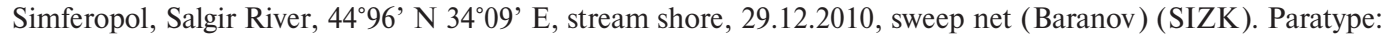
1 male (in glycerol-gelatin), same data as holotype (VAB).

Diagnosis. This species can be distinguished by a combination of the following features:- uniserial scutellars, double inferior volsella, unusual triangular shape of the gonostylus, squama with many (38-40) biserial setae; 12-13 dorsocentrals, 7 prealars, 12 scutellars.

It is very similar to Parorthocladius unicentrus Lui and Wang, 2005 in the general shape of the hypopygium and the double inferior volsella, but it differs by having double tibial spurs on the mid and hind tibia and by the shape of the oral projection on the transverse sternapodeme. It differs from $P$. nudipennis by the biserial setae on the squama, the shape of the gonostylus and the oral projection on the tranverse steranapodeme, but the virga and sternapodeme shape are very similar in both.

Description. Male adult $(\mathrm{n}=2)$.

Total length $4.56 \mathrm{~mm}$. Wing length $2.63 \mathrm{~mm}$. Total length/wing length ratio 1.73 . brownish

Coloration. Head, thorax, abdominal segments and legs dark brown. Wings light

He ad. Antenna with 13 flagellomers. Length of flagellomeres (in $\mu$, from $1^{\text {st }}$ to $13^{\text {th }}$ ) : $69: 23: 23: 23: 23: 23: 25: 28: 28: 25: 28: 28: 588$. Terminal flagellomere without strong subapical seta. $\mathrm{AR}=1.69$. Temporal setae 15 , including 7 inner verticals and
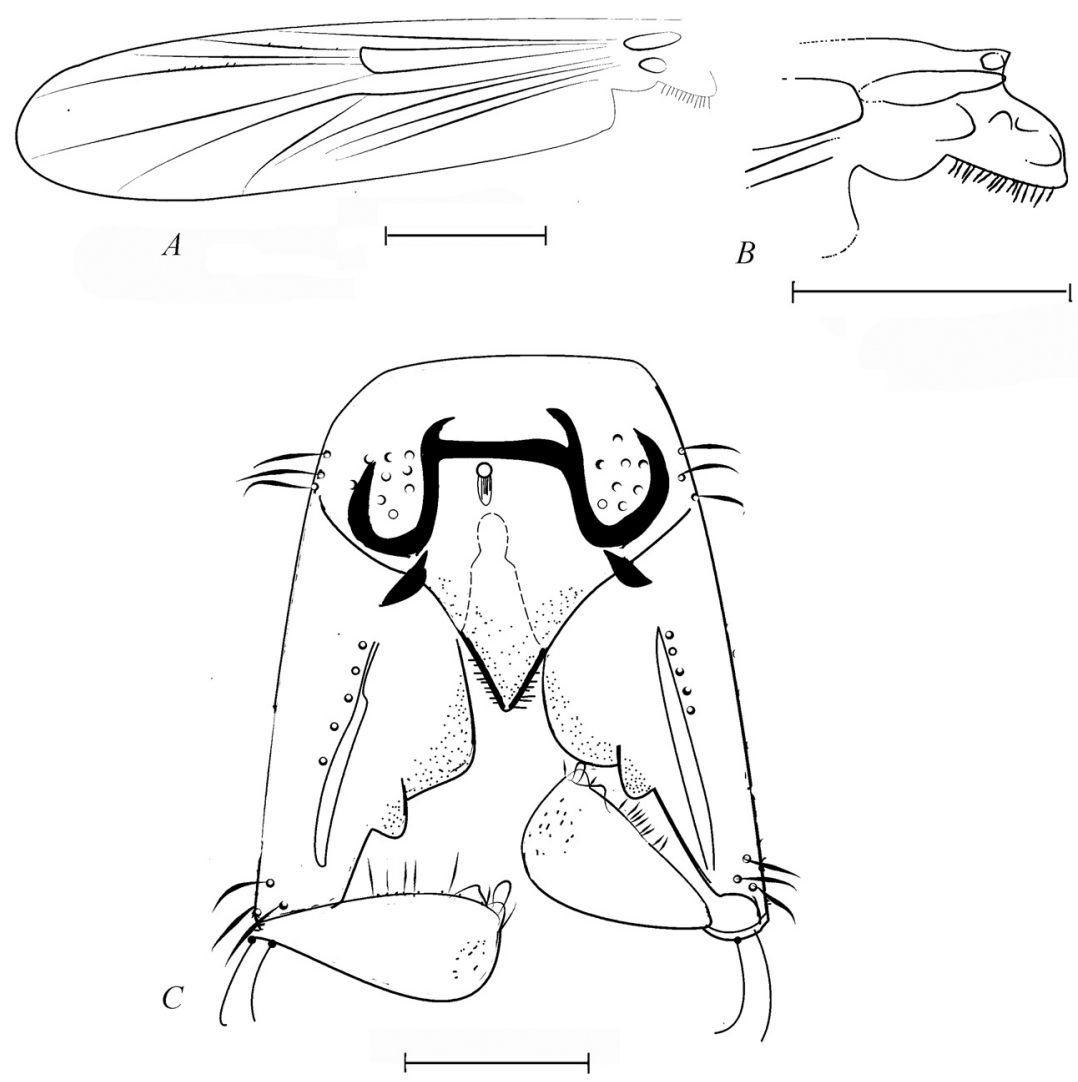

Fig. 1. Parorthocladius korneyevi: $A$ - whole wing; $B$ - wing base; $C$ - hypopygium. Scale bars $50 \mu \mathrm{m}$.

Рис. 1. Parorthocladius korneyevi: $A$ - крыло, общий вид; $B$ - основа крыла; $C$ - гипопигий. Масштабные линейки 50 мкм. 
Table 1. P. korneyevi. Lengths $(\mu \mathrm{m})$ and ratios of leg segments (holotype $\sigma^{\prime)}$

Таблиц 1. P. korneyevi. Длины (мкм) и пропорции сегментов ног (голотип о")

\begin{tabular}{c|c|c|c|c|c|c|c|c}
\hline Leg & Fe & Ti & Ta1 & Ta2 & Ta3 & Ta4 & Ta5 & LR \\
\hline P1 & 947 & 815 & 676 & 316 & 263 & 158 & 132 & 0,82 \\
P2 & 1078 & 999 & 526 & 263 & 210 & 132 & 118 & 0,52 \\
P3 & 1052 & 1078 & 526 & 263 & 210 & 105 & 105 & 0,48 \\
\hline
\end{tabular}

8 outer verticals. Clypeus with 18 setae. Cibarial pump with distinct cornua. Palpomere lengths (in $\mu \mathrm{m}$, from P1 to P5) $92: 73.6: 103.5: 87.4: 115$.

Thorax. Antepronotum with 5-6 lateral setae. Acrostichals absent. Dorsocentrals 12-13, prealars 7. Scutellum with 12 uniserial setae.

Wing (fig. 1, $A, B$ ). Anal lobe well developed. Costal extension $80.5 \mu \mathrm{m}$ long. $\mathrm{VR}=1.16$ Brachiolum with 6 seta; $\mathrm{R}_{4+5}$ with 6 setae, $\mathrm{R}_{1}$ with 3 setae, other veins bare. End of $\mathrm{Cu}_{1}$ slightly recurved. Squama with 38-40 biserial setae, alula bare.

Legs. Mid and hind tibiae with double spurs but without denticles. Two pseudospurs present on tarsomere III of mid and hind legs (table 1):

Hy popygium (fig. 1, C). Anal point parallel-sided with blunt apex, $58.5 \mu \mathrm{m}$ long, $46 \mu \mathrm{m}$ wide at base, anal point length/width ratio 1.3, with 14-16 lateral setae. Gonocoxite with 16-18 long setae. Phallapodeme with hooked apex, $70 \mu$ long; transverse sternapodeme arcuate, $100 \mu \mathrm{m}$ long, with hooked oral projection. Laterosternite IX with 3 setae, tergite IX with 16 setae. Gonocoxite $304 \mu \mathrm{m}$ long. Gonostylus triangular, $98 \mu \mathrm{m}$ long, with triangular preapical crista and 10 setae on the inner side. Inferior volsella double, dorsal part triangular with numerous microtrichia, ventral part oval and with more than 35 long setae.

Female and immature stages. Unknown.

Distribution and ecology. The species is known only from the type locality and was collected by sweep net. Adult males were collected during the snowfall, from last year's grass at a spring shore, together with Micropsectra atrofasciata (Kieffer, 1911), air temperature $+4^{\circ} \mathrm{C}$.

Ety mology. Named in honour of Valery A. Korneyev (I. I. Schmalhausen Institute of Zoology, National Academy of Sciences of Ukraine, Kyiv), for his contribution to the study of Ukrainian Diptera.

\section{Genus Prosmittia Brundin, 1956}

\section{Type species: Pseudosmittia jemtlandica Brundin, 1947}

The genus Prosmittia includes 15 species (14 in the Palaearctic and one in the Nearctic) (Sæther et al., 2000; Yamamoto, 2004; P. Ashe, pers. comm.). The genus was recently reviewed by Makarchenko (2007). Since 2007 two additional species have been described, P. verae Krasheninnikov et Makarchenko, 2008 from the Caucasus (Krasheninnikov, Makarchenko, 2008) and P. anyuiica Makarchenko and Makarchenko, 2009 from the Russian Far East (Makarchenko, Makarchenko, 2009). Most species of the genus have been described from Japan and only three species, $P$. jemtlandica, $P$. rectangularis Tuiskunen, 1985 and $P$. verae are known from Europe. Based on material from southern Crimea (Yalta) a new species of Prosmittia is described below.

Prosmittia valentinae Baranov, sp. n. (fig. 2, $A-C$ )

Type material. Holotype male, slide mounted in glycerol-gelatin. Ukraine: Crimean Peninsula, Yalta, mouth

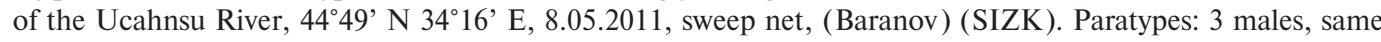
data as the holotype (VAB).

Diagnosis. This species is similar to Prosmittia kamiquarta (Sasa, Hirabayashi, 1991) in having a triangular anal point and in the general shape of the gonocoxite, but differs 
in having an apically wide gonostylus, and with the crista and the ventral part of the inferior volsella being very small and membranous.

Description. Total length $2.5-3.02 \mathrm{~mm}$. Wing length $1.84 \mathrm{~mm}$. Total length/wing length ratio 1.35 .

Coloration. Thorax and abdominal tergites dark brown, sternites of abdomen yellow, legs light-brown.

He ad. All specimens lacking antenna, after preservation in alcohol, except holotype, with badly preserved antenna. That is why accurate antenna description impossible. $\mathrm{AR}=1.33$. Apex of the last flagellomere of antenna cardiform. Eyes bare, without dorsomedial extension. Palpomere lengths (in $\mu \mathrm{m}, \mathrm{P} 1$ to P5) : $26: 92: 98: 100: 117$.

Th orax. Antepronotum with 4 lateral setae. Acrostichal setae absent. Dorsocentral setae 12 , prealar setae 6 .

Legs. Mid and hind tibia with single tibial spur; no denticles. Tibial comb of mid and hind legs with 9 setae. Lengths $(\mu \mathrm{m})$ and proportions of legs as in table 2.

Hy p opygium (fig. 2, $A, B$ ). Anal point triangular, with dense microtrichia, in middle of tergite, not extended beyond posterior margin of tergite IX. Total length of anal point from 30 to $49 \mu \mathrm{m}$. Anal point width $30 \mu \mathrm{m}$; length to width ratio $=1.6$. Laterosternite IX with 3 setae, tergite IX bare. Phallapodeme $46 \mu \mathrm{m}$ long; transverse sternapodeme arcuate, without oral projection. Gonocoxite 147-176 $\mu \mathrm{m}$ long. Gonostylus with distinct crista, 69-79 $\mu \mathrm{m}$ long, with 2 setae on inner side, near apex. Inferior volsella double, dorsal part triangular with numerous microtrichia, ventral part indistinct, membranous.

Female and immature stages. Unknown.

Distribution and ecology. This species is known only from the type locality and was collected using a sweep net. Adult males were collected near the river mouth,

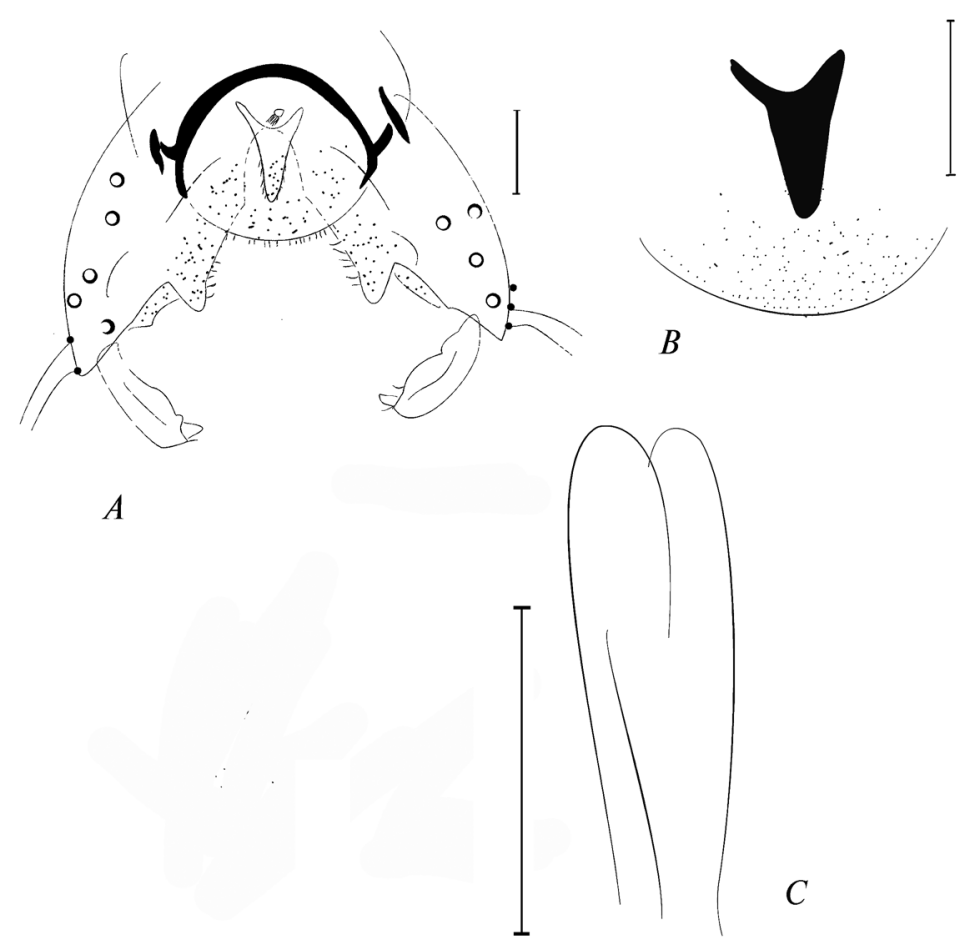

Fig. 2. Prosmittia valentinae: $A-$ hypopygium; $B-$ Anal point and tergite $\mathrm{X} ; C-$ apex of antenna. Scale bars $50 \mu \mathrm{m}$.

Рис. 2. Prosmittia valentinae: $A-$ гіпопігій; $B-$ анальний отросток и тергит $\mathrm{X} ; C-$ вершина антенны. Масштабные линейки 50 мкм. 
Table 2. P. valentinae. Lengths $(\mu \mathrm{m})$ and ratios of leg segments $\left(4 \sigma^{\prime \prime}\right.$ measured)

Т а б л и ц 2. P. valentinae. Длины (мкм) и пропорции сегментов ног (измерены 4 ơ)

\begin{tabular}{c|c|c|c|c|c|c|c|c}
\hline Leg & $\mathrm{Fe}$ & $\mathrm{Ti}$ & $\mathrm{Ta} 1$ & $\mathrm{Ta} 2$ & $\mathrm{Ta}$ & $\mathrm{Ta} 4$ & $\mathrm{Ta} 5$ & LR \\
\hline P1 & $294-394$ & $578-637$ & $294-368$ & $159-167$ & $98-132$ & $49-79$ & $39-52.6$ & $0.46-0.63$ \\
P2 & $510-526$ & $526-588$ & $263-294$ & $147-157$ & $98-131$ & $69-80$ & $78-105$ & 0.5 \\
P3 & $578-588$ & $526-637$ & $263-343$ & $132-188$ & $105-147$ & $78-79$ & $53-59$ & $0.5-0.53$ \\
\hline
\end{tabular}

at the sea shore, while swarming above the water. They were collected together with specimens of Brillia bifida (Kieffer, 1909) and Paramerina sp.

Etymology. Named in honour of Valentina V. Inshina, whose assistance and support made this study possible.

Along with the two new species described above, three species of Orthocladiine not previously known to occur in the Ukraine (all collected in the Crimea) are recorded here for the first time.

Bryophaenocladius akiensis (Sasa, Shimomura et Matsuo, 1991) (fig. 3)

Material. Ukraine: Crimean Peninsula, Yalta, Uchansu River, near Uchansu waterfall, $44^{\circ} 49^{\prime} \mathrm{N}$

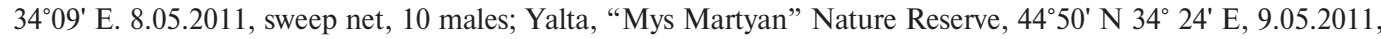
sweep net, 1 male (Baranov) (VAB).

Re marks. Specimens were collected in a wide range of conditions, from a wet forest at the base of a waterfall to dry Mediterranean shrub at the sea shore.

Description. European Russia, doubtful in Medeira, Japan and the Russian Far East (Yamamoto, 2004; Makarchenko, 2006, 2007; Sæther, Spies, 2011). The first record from Ukraine.

Corynoneura lacustris Edwards, 1924

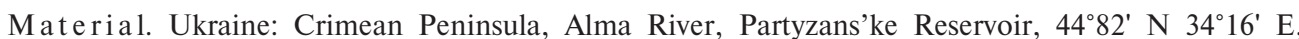
26.03.2011, on snow, sweep net, 2 males (Prokopov) (VAB).

Distribution. It is widespread in western Europe but also occurs in then Near East, North Africa, the Nearctic Region and the Russian Far East (Ashe, Cranston 1990; Makarchenko, 2006; P. Ashe, pers. comm.). The first record from Ukraine.

Metriocnemus eurynotus (Holmgren, 1883)

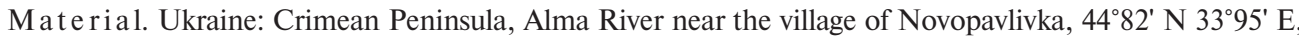
19.03.2011, sweep net, 4 males (Prokopov); Kharkiv Region, Kharkiv, Sharzhinka River in the Central City Park, 5001' N 36 $13^{\prime}$ E, 2.05.2011, sweep net, 5 males (Baranov) (VAB).

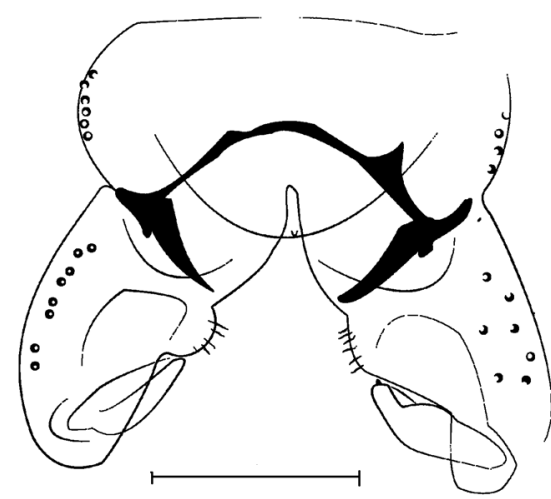

Fig. 3. Bryophaenocladius akiensis: Hypopygium. Scale bar $50 \mu \mathrm{m}$.

Рис. 3. Bryophaenocladius akiensis: Гипопигий. Масштабная линейка 50 мкм. 
Re marks. In the Crimea, the specimens were collected on snow, in Kharkiv, at the shore of a cold spring (summer temperature up to $9^{\circ} \mathrm{C}$ ).

Description. It is widespread in the western Palaearctic but also occurs in Asiatic Russia (East Siberia, Far East), China, Japan as well as the Nearctic and Oriental Regions (Ashe, Cranston, 1990; Makarchenko, 2006; P. Ashe, pers. comm.). The first record from Ukraine.

I wish to express my sincere thanks to Valery A. Korneyev (I. I. Schmalhausen Institute of Zoology, National Academy of Sciences of Ukraine, Kyiv, Ukraine) and Humberto F. Mendes (University of Bergen, Norway) for reading early versions of this manuscript and for useful critical comments on the text and figures. I thank two anonymous referees for carefully reading the manuscript and for constructive criticism. Some specimens used in this study were borrowed through the kindness of Grigory A. Prokopov (V. I. Vernadsky National University of Tavrida, Ukraine). I also wish to thank Andrei Krasheninnikov (Perm State University, Russia) and Masaru Yamamoto (Kankyou-kagaku kabushiki-gaishya, Japan), who sent me copies of papers important for this study.

Special thanks are due to Alexandr G. Vasenko (Ukrainian Scientific Research Institute of Ecological Problems, Kharkiv, Ukraine) for access to laboratory facilities, and my wife, Valentina V. Inshina, for her constant support, assistance and inspiration for my research on chironomids.

Ashe P., Cranston P. S. Family Chironomidae // Catalogue of Palaearctic Diptera. Volume 2. Psychodidae-Chironomidae / Eds Á. Soós, L. Papp. - Amsterdam : Elsevier, 1990. - P. 1-499.

Baranov V. A. A preliminary annotated checklist of non-biting midges (Diptera, Chironomidae) of Ukraine // Ukrainska Entomofaunistyka. - 2011. - 2, N 1. - P. 7-24. - Ukrainian : Баранов В. О. Попередній анотований список комарів-дзвінців (Diptera, Chironomidae) України.

Brundin L. Zur Systematik der Orthocladiinae (Diptera, Chironomidae) // Rep. Inst. Freshwater Res. Drottningholm. - 1956. - N 37. - P. 5-185.

Krasheninnikov A. B., Makarchenko E. A. Prosmittia verae sp. n. - a new chironomid species (Diptera: Chironomidae: Orthocladiinae) from the environs of Sochi Town (the northern Caucasus) // Caucasian Entomological Bulletin. - 2008. - 4, N 3. - P. 359-361. - Russian : Крашенинников А. Б., Макарченко E. A. Prosmittia verae sp.n. - новый вид комаров-звонцов (Diptera, Chironomidae) из окрестностей Сочи (Северный Кавказ).

Lui Y., Wang X. A review of the genus Parorthocladius Thienemann from China (Diptera: Chironomidae: Orthocladiinae) // Zootaxa. - 2005. - N 802. - P. 1-8.

Makarchenko E. A., Makarchenko M. A. Subfamily Orthocladiinae // Key to the insects of Russian Far East. Vol. 6. Diptera and Siphonaptera. Part 4 / Ed. A. S. Lelei. - Vladivostok : Dal'nauka, 2006. P. 280-671. - Russian : Макарченко E. А., Макарченко М. А. Подсем. Orthocladiinae.

Makarchenko E. A., Makarchenko M. A. Chironomids of Prosmittia Brundin (Diptera: Chironomidae: Orthocladiinae) from the Russian Far East // Russian Entomological J. - 2007. - 16, N 1. - P. 122.

Makarchenko E. A., Makarchenko M. A. New findings of chironomids (Diptera, Chironomidae) in Far East and bordering territories// Eurasian Entomological J. - 2009. - 8, N 1. - P. 117-124.

Sxther O. A. Glossary of chironomid morphology terminology (Chironomidae, Diptera) // Entomologica scandinavica. - 1980. - Suppl. 14. - P. 1-51.

Sæther O. A., Ashe P., Murray D. A. Family Chironomidae // Contributions to a Manual of Palaearctic Diptera (with special reference to the flies of economic importance) / Eds L. Papp, B. Darvas. - Budapest : Science Herald, 2000. - Vol. 4, A. 6.- P. 113-334.

Sxther O. A., Spies M. Fauna Europaea: Chironomidae // Fauna Europaea: Diptera Nematocera. Fauna. Fauna Europaea, version 2.2 / Ed. H. de Jong. - 2011. - http://www.faunaeur.org. - Accessed 20.09.2011.

Yamamoto M. A catalog of Japanese Orthocladiinae (Diptera, Chironomidae)// Makunagi (Acta Dipterologica). - 2004. - 21. - P. 1-121.

Yamamoto M. A new species of Parorthocladius Thienemann (Diptera: Chironomidae) from Toyama Prefecture, Honshu, Japan, with distributional data of some chironomid species // Bulletin of the Toyama Science Museum. - 2011. - N 34. - P. 31-36. 